\title{
A DENSITY MANAGEMENT DIAGRAM FOR EVEN-AGED EUCALYPTUS DUNNII STANDS IN SOUTHERN BRAZIL
}

\author{
Krefta SM${ }^{1}$, Hess $\mathrm{AF}^{1}$, Atanazio KA ${ }^{2}$, Da Silveira AC ${ }^{1}$, Schorr LPB ${ }^{3}$, , Borsoi GA ${ }^{1}$, Costa $\mathbf{E A}^{4}$, Klein \\ DR $^{1}$ \& Stepka TF ${ }^{1}$
}

\author{
${ }^{1}$ Santa Catarina State University, Department of Forest Engineering, 2090 Luiz de Camões Avenue, Conta Dinheiro, \\ Lages, Santa Catarina, 88520-000, Brazil. \\ ${ }^{2}$ Federal University of Viçosa, Department of Forest Engineering, Peter Henry Rolfs Road, Campus Universitário, Viçosa, \\ Minas Gerais, 36570-900, Brazil. \\ ${ }^{3}$ Federal University of Lavras, Department of Forest Sciences, Campus Universitário, Mailbox 3037, Lavras, Minas Gerais, \\ 37200-900, Brazil. \\ ${ }^{4}$ Federal University of Uberlândia, Department of Forest Engineering, Monte Carmelo, Minas Gerais 38500-000, Brazil.
}

*lpbs93@gmail.com

Submitted June 2020; accepted January 2021

\begin{abstract}
Density management diagrams (DMD) are graphic models that describe the forest stand dynamics, and they are extremely useful to regulate tree density. This study aimed to develop a DMD for Eucalyptus dunnii stands located in the municipality of Rio Negrinho, Santa Catarina, Brazil. Plots of $400 \mathrm{~m}^{2}$ were inventoried at the ages of 2, 3 and 4 years. The following variables were determined for the stands: the basal area per hectare, the number of trees per hectare and the geometric mean diameter. The Reineke model (1933) was fitted and its intercept value recalculated to define the maximum density line, reaching a determination coefficient of 0.5461. With the elaborated DMD of the current stand, a thinning can be simulated at 5.8 years with a cut at 7 years, taking into consideration a diametric increase of $2.41 \mathrm{~cm}$. In addition, another scenario was simulated with thinning occurring at 4 and 6 years and a cut at 7.5 years. With the execution of this work, the DMD proved to be an efficient tool for the elaboration of forest management plans.
\end{abstract}

Keywords: Thinning, forest yield, forest management, density management diagrams, Eucalyptus dunnii

\section{INTRODUCTION}

The importance of forest resources to meet human needs is recognised around the world. For example, wood is used over the centuries for various purposes, and thus, forest plantations with fast-growing species such as the Eucalyptus emerged. Currently, Eucalyptus wood is widely used and is provided by short-time production cycles. In Brazil, Eucalyptus wood is prominent in the economic scenario and the trade balance, as well as creating employment opportunities in 17 states, and presenting large investments in recent years (Marangon 2015, Retslaff et al. 2016).

Numerous forest stands are empirically conducted in Brazil. Commonly, it results in highly competitive stands causing poor quality timber and economic losses from mortality and pests. However, stands with good characteristics depend on silvicultural practices and management. Therefore, knowledge about the dynamics of growth and interaction between individuals is indispensable (Lima et al. 2013). The knowledge should include the detection of competition, since, according to Scheeren et al. (2004), with the development of trees, their crowns and roots gradually need larger spaces to continue to grow. When this space is restricted, there is a collapse of individuals in the lower strata, which requires the need for silvicultural interventions in the forest stand.

According to Thomas (2009), stand density estimates can be constructed for short periods of time, serving to determine thinning weights and to perform interventions at a given time. In addition, for long periods, it supports the creation of a thinning plan for the entire rotation. This shows that density regulation is the key to continuous volume production of the forest.

The use of density management diagrams (DMD) is to use a practical technique, based on the theory of self-thinning of pure stands 
(Schneider et al. 2009). Thus, DMD studies are useful tools for forest managers, replacing the traditional experiments for defining optimal spacing. However, there is still little research on the subject, especially in Brazil and for leafy species (Schneider 2008).

According to Marangon (2015), the planning of thinning regimes is one of the main uses of DMD because it enables the managers to determine the time and intensity of thinning, and to reach the objectives outlined. Also, it can be used to compare and to define a set of cutting planes. Moreover, diagrams become instruments to understand the population dynamics and the implications of density interventions.

With the use of DMD, the degree of competition between individuals in forests can be defined by the mean of a series of parallel lines, determined from the self-thinning line. Based on this, the competition zones for the study stand can be defined (Reid 2004). It is also possible to predict future changes in the mean diameter, height, density and volume of pure stands (Long \& Smith 1985).

In this context, the hypothesis of this work is that the construction of DMD will help in the planning of silvicultural interventions for forest stands. Thus, this study aimed to develop a DMD as a function of the number of trees per hectare, the quadratic mean diameter and the basal area per hectare for stands of Eucalyptus dunnii in the municipality of Rio Negrinho, Santa Catarina, Southern Brazil.

\section{MATERIALS AND METHODS}

\section{Studied area}

The present work was performed in the municipality of Rio Negrinho (latitude $26^{\circ} 15^{\prime}$ and longitude $49^{\circ} 31^{\prime}$, with altitude varying between 800 and $1200 \mathrm{~m}$, located in the microregion of North Plateau of Santa Catarina State (INPE, 2009). Experimental areas of E. dunnii stands with ages between 2 and 4 years were used for the study. These areas belonged to a forestry company, using them for energy purposes.

According to Bognola (2007), Rio Negrinho is inserted in the extreme north of the state, having as border the state of Paraná, and it is located between the Serra do Mar and the Patamar de Mafra. The relief of the region is almost flat, consisting predominantly of a hill surface. Kobiyama et al. (2007) reported that geology is formed by Paleozoic sedimentary rocks.

The region's climate is classified as Cfb, that is, Mesothermal Humid Temperate, with no defined dry season, with average annual temperatures of $17^{\circ} \mathrm{C}$, reaching $3{ }^{\circ} \mathrm{C}$ during the coldest month and not exceeding $22^{\circ} \mathrm{C}$ during the hottest month (Alvares et al. 2014).

The data used in this study was obtained from forest stands originating from clonal seedlings of E. dunnii (clone 7003), which were installed in December 2011, 2012 and 2013. In the implantation of these stands, soil preparation was carried out using the minimum tillage method, that is, with subsoiling up to $0.4 \mathrm{~m}$ in depth, performed at $3.0 \mathrm{~m}$ spacing, and the planting had a standard spacing of $3 \times 2 \mathrm{~m}(1667$ trees $\left.h^{-1}\right)$.

\section{Data collection}

Data were collected in 2, 3 and 4-year-stands. Simple random sampling was carried out, through the installation of $400 \mathrm{~m}^{2}$ sample units. Thus, 47 sample units were installed, distributed according to the structure presented in Table 1. The diameter at breast height $(\mathrm{DBH})$ of all trees were collected in these sample units.

\section{Data processing}

Each sample unit was used to determine:

- Actual number of trees per hectare $(\mathrm{Nr})$, determined by the product resulting from the number of trees in 20\% of the plot and area of one hectare; the ratio is the area occupied by $20 \%$ of these trees (equation 1):

$$
\mathrm{A}=\frac{\mathrm{N} 20 \% * 10000}{\mathrm{~A} 20 \%}
$$

where $\mathrm{Nr}=$ actual number of trees per hectare $\left(\right.$ trees $\left.\mathrm{ha}^{-1}\right), \mathrm{N} 20 \%=$ number of trees in $20 \%$ of the sample unit and A20\% = area occupied by $20 \%$ of these trees.

- Quadratic mean diameter (dq) (equation 2):

$$
\mathrm{dq}=\sqrt{\frac{4 \mathrm{~g}}{\pi}}
$$

where $\mathrm{dq}=$ quadratic mean diameter $(\mathrm{cm})$ and $\mathrm{g}=$ average cross-sectional area $\left(\mathrm{cm}^{2}\right)$. 
- Average basal area per hectare $\left(\mathrm{G} \mathrm{ha}^{-1}\right)$ (equation 3):

$$
\mathrm{G}=\mathrm{Nr} \sqrt{\frac{4 \mathrm{~g}}{\pi}}
$$

where $G h^{-1}=$ average basal area per hectare $\left(\mathrm{m}^{2} \mathrm{ha}^{-1}\right), \mathrm{Nr}=$ actual number of trees $\mathrm{ha}^{-1}$ and $\mathrm{dq}=$ quadratic mean diameter $(\mathrm{cm})$.

The relationship between the number of trees per hectare $(\mathrm{Nr} / \mathrm{ha})$ and the corresponding $\mathrm{dq}$ was determined using Reineke's model (1933) in a linear form (equation 4):

$$
\ln \left(\mathrm{N} \mathrm{ha}^{-1}\right)=\beta 0+\beta 1 \ln (\mathrm{dq})+\varepsilon
$$

where: $\mathrm{N} \mathrm{ha}^{-1}=$ number of trees per hectare, $\mathrm{dq}=$ quadratic mean diameter $(\mathrm{cm}), \beta 0 \& \beta 1=$ estimated regression coefficients and $\varepsilon=$ residual error

According to Thomas (2009), Reineke's regression model estimates the maximum population density, however, the result of this regression model is the estimated average of the observed values. Therefore, this value does not express the maximum density, since there are values above and below an average, so the values above represent the maximum density.

As a result, for the construction of line A, which describes the maximum occupation density, a new intercept value was defined after adjusting equation 4, increasing it until the model covered the observed data. That is, for the definition of the maximum line, the level of the equation was changed through attempts, which makes the process as biological as possible According to Selle et al. (2010), the maximum line indicates the upper limit of the capacity that the site supports, corresponding, to the theoretical relationship that describes the trajectory of the number of trees that are in full occupation density.
Line A was built from stands in maximum stock, which had low natural mortality. Its definition included the youngest ( 2 years old) to the oldest (4 years old) stands. It is important to highlight that not all stands had the standard 3 $\times 2 \mathrm{~m}$ spacing, as some places were larger while others were smaller. Thus, in some cases, the expected density of 1667 trees ha ${ }^{-1}$ exceeded. However, this fact turned out to be a positive aspect because it was possible to cover different simulations for density.

The management range between lines $\mathrm{B}$ and $\mathrm{C}$, corresponding to the phases of mortality onset and maximum productivity, respectively, were fixed in relation to line $\mathrm{A}$, considering values of $55 \%$ for line B and $50 \%$ for line $\mathrm{C}$. Thus, the management range was stipulated in a range of $15 \%$. Line $\mathrm{D}$, describing crown occupation, was set at $45 \%$. These values were determined based on the work of Marangon et al. (2017) who built DMD for E. grandis. According to Costa et al. (2016), these line amplitudes may change according to the objectives established in the management of the forest.

In addition, the management range was located between these weights. Since the desired product was energy use, it was not necessary to manage the forests with high production capacity, as the maximum diameter was $18 \mathrm{~cm}$. As described by Thomas (2009) it is possible to increase production by densifying the area to an optimum limit. However, the maximum density is also not of interest, because it can cause higher competition and suppressed individuals.

Statistical analyses (SAS 9.3), coefficient of determination $\left(\mathrm{R}^{2}\right)$, standard error of the percentage estimate (Syx\%) and graphic analysis of the residues according to estimated values, were used to verify the performance of the equations. PROC REG procedure was used to estimate the regression coefficients with the ordinary least squares method.

Table 1 Number of sample units at each age and total units evaluated in Eucalyptus dunnii stands located in Rio Negrinho, Santa Catarina, Brazil

\begin{tabular}{ccc}
\hline Age (years) & Area (ha) & Sample units (number) \\
\hline 2 & 64.8 & 13 \\
3 & 44.6 & 9 \\
4 & 123.3 & 25 \\
\hline Total & 232.7 & 47 \\
\hline
\end{tabular}




\section{RESULTS}

The results showed a great variation between the maximum and minimum values found for $\mathrm{G} \mathrm{ha}^{-1}$, $\mathrm{dq}$ and $\mathrm{Nr}_{\mathrm{ha}} \mathrm{a}^{-1}$, with an average $\mathrm{G} \mathrm{ha} \mathrm{a}^{-1}$ of $19 \mathrm{~m}^{2} \mathrm{ha}^{-1}$, and a maximum reaching $40 \mathrm{~m}^{2} \mathrm{ha}^{-1}$, showing an over-stocked stand. The highest dq value was $20 \mathrm{~cm}$ and the minimum value was $8 \mathrm{~cm}$. The variation in $\mathrm{Nr} \mathrm{ha}^{-1}$ was also large, showing once again the problems with spacing.

The analysed stands are characterised in Table 2, through which the average, minimum and maximum values for mean square diameter, basal area and number of trees $\mathrm{ha}^{-1}$ can be observed. The table shows that the variation between the minimum and maximum values for the analysed variables was high, with an emphasis on the number of trees ha-1. Figure 1 shows that the values estimated by Reineke's model (1933) were able to describe the observed data, thus ensuring that line A was constructed in the most appropriate way.
The management diagram developed for the basal area per hectare, based on the interaction of $\mathrm{Nr} \mathrm{ha}^{-1}$ and dq, can be seen in Figure 2. The proposed management range was between the values of 55 and $50 \%$ in relation to line A. In addition, it can also be seen that the amplitude of coverage of dq is from 8 to $22 \mathrm{~cm}$ in classes of $2 \mathrm{~cm}$, depending on the data sampled in the field.

The thinning simulations for the stand are shown in Tables 3 and 4, indicating the weight of the proposed thinning, as well as the remaining ones, referring to the number of trees $\mathrm{ha}^{-1}$ and basal area.

With the inclusion of the data observed in the field in DMD, it was clear that they were contemplated by the amplitude of the constructed DMD. Figure 3 shows the two scenarios built, that simulate the possible thinning described in Tables 3 and 4. With the aid of the figure, one thinning was suggested in $\mathrm{A}$, while two thinnings were suggested in $\mathrm{B}$.

Table 2 Statistical summary of the characteristics of the sampled trees of Eucalyptus dunnii stands located in Rio Negrinho, Santa Catarina, Brazil

\begin{tabular}{lccc}
\hline Variable & Average & Minimum & Maximum \\
\hline $\mathrm{dq}(\mathrm{cm})$ & 13 & 8 & 20 \\
$\mathrm{G} \mathrm{ha}^{-1}\left(\mathrm{~m}^{2} \mathrm{ha}^{-1}\right)$ & 19 & 8 & 40 \\
$\mathrm{Nr} \mathrm{ha}^{-1}$ & 1519 & 975 & 2000 \\
\hline
\end{tabular}

$\mathrm{dq}=$ quadratic mean diameter $(\mathrm{cm}), \mathrm{G} \mathrm{ha}^{-1}=$ basal area per hectare $\left(\mathrm{m}^{2} \mathrm{ha}^{-1}\right)$, $\mathrm{Nr}=$ actual number of trees per hectare

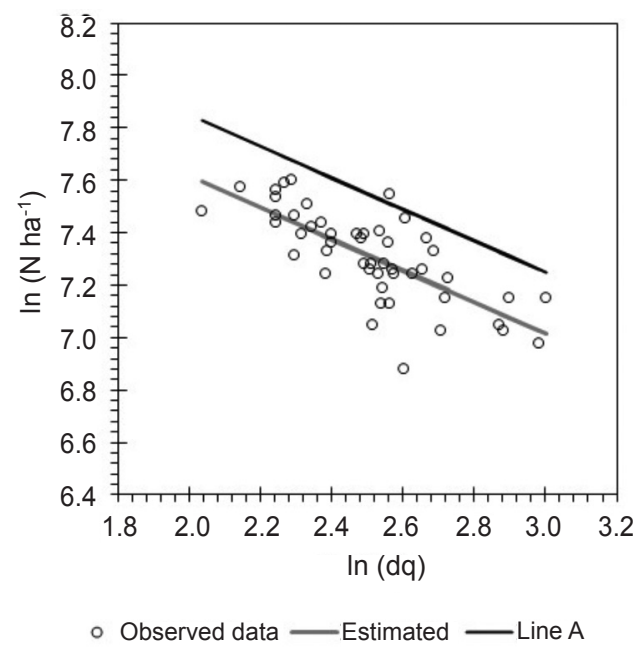

Figure 1 Fitted into Reineke model (1933) to describe $\ln \left(\mathrm{N} \mathrm{ha}^{-1}\right)$ as a function of $\ln (\mathrm{dq})$ for Eucalyptus dunnii stands located in Rio Negrinho, Santa Catarina, Brazil; estimation = $\ln$ $\left(\mathrm{N} \mathrm{ha}^{-1}\right)=8.81664-0.60023 \ln (\mathrm{dq})+\varepsilon ;$ line $\mathrm{A}=\ln \left(\mathrm{N} \mathrm{ha}^{-1}\right)=9.050000-0.60023 \ln (\mathrm{dq})+\varepsilon$ 


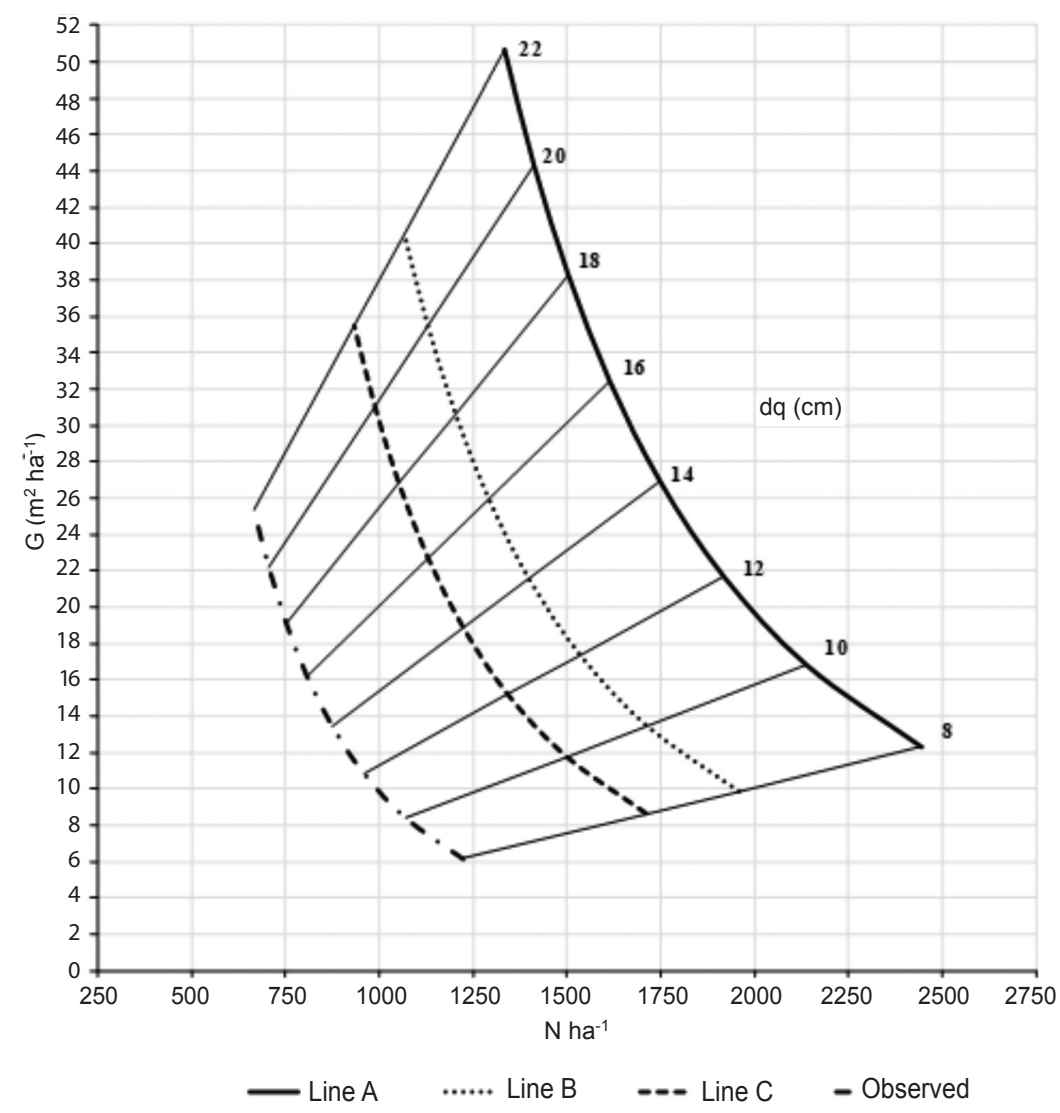

Figure 2 Density management diagram (DMD) of the basal area $\left(\mathrm{G} \mathrm{ha}^{-1}\right)$ related to the number of trees $\left(\mathrm{Nr} \mathrm{ha}{ }^{-1}\right)$ per hectare and quadratic mean diameter (dq) for Eucalyptus dunnii stands located in Rio Negrinho, Santa Catarina, Brazil

Table 3 Simulation 1 for execution of thinning for Eucalyptus dunnii stands located in Rio Negrinho, Santa Catarina, Brazil

\begin{tabular}{cccccccc}
\hline \multirow{2}{*}{$\mathrm{dq}(\mathrm{cm})$} & \multirow{2}{*}{ Age (years) } & \multicolumn{2}{c}{ Remaining } & \multicolumn{3}{c}{ Thinning } \\
\cline { 3 - 7 } & $\mathrm{Nr} \mathrm{ha}^{-1}$ & $\mathrm{G}\left(\mathrm{m}^{2} \mathrm{ha}^{-1}\right)$ & $\mathrm{Nr} \mathrm{ha}^{-1}$ & ${\mathrm{G}\left(\mathrm{m}^{2} \mathrm{ha}^{-1}\right)}_{\% \mathrm{Nr} \mathrm{ha}^{-1}} \% \mathrm{G}\left(\mathrm{m}^{2} \mathrm{ha}^{-1}\right)$ \\
\hline 13 & - & 1550 & 21.0 & - & - & - & - \\
14 & 5.8 & 1252 & 19.3 & 298 & 1.7 & 19.2 & 8.8 \\
17 & 7 & 1252 & 28.4 & - & - & - & - \\
\hline
\end{tabular}

$\mathrm{dq}=$ quadratic mean diameter $(\mathrm{cm}), \mathrm{G} \mathrm{ha}^{-1}=$ basal area per hectare $\left(\mathrm{m}^{2} \mathrm{ha}^{-1}\right), \mathrm{Nr}=$ actual number of trees per hectare

Table 4 Simulation 2 for execution of thinning for Eucalyptus dunnii stands located in Rio Negrinho, Santa Catarina, Brazil

\begin{tabular}{cccccccc}
\hline \multirow{2}{*}{$\mathrm{dq}(\mathrm{cm})$} & Age (years) & \multicolumn{3}{c}{ Remaining } & \multicolumn{3}{c}{ Thinning } \\
\cline { 3 - 7 } & $\mathrm{Nr} \mathrm{ha}^{-1}$ & $\mathrm{G}\left(\mathrm{m}^{2} \mathrm{ha}^{-1}\right)$ & $\mathrm{Nr} \mathrm{ha}^{-1}$ & ${\mathrm{G}\left(\mathrm{m}^{2} \mathrm{ha}^{-1}\right)}$ & $\% \mathrm{Nr} \mathrm{ha}^{-1}$ & $\% \mathrm{G}\left(\mathrm{m}^{2} \mathrm{ha}^{-1}\right)$ \\
\hline 9 & - & 1850 & 12.0 & - & - & - & - \\
10 & 4 & 1500 & 12.0 & 350 & - & 18.9 & - \\
13 & - & 1500 & 20.0 & - & - & - & - \\
14.5 & 6 & 1200 & 20.0 & 300 & - & 20.0 & - \\
18 & 7.5 & 1200 & 30.5 & - & - & - & - \\
\hline
\end{tabular}

$\mathrm{dq}=$ quadratic mean diameter $(\mathrm{cm}), \mathrm{G}=$ basal area per hectare $\left(\mathrm{m}^{2} \mathrm{ha}^{-1}\right), \mathrm{Nr}=$ actual number of trees per hectare 


\section{DISCUSSION}

Large variations in forest variables can be a result of inadequate population density. Therefore, the exaggerated number of trees in a given area causes strong competition between plants. It also occurs because of growth and increase in $\mathrm{DBH}$ that decreases the space for trees, and generally tree density decreases with increase in $\mathrm{DBH}$. Thus, thinning gains importance as a regulator of density, space available for growth and spatial distribution (Schneider 2004).

For this purpose, the model by Reineke (1933) was fitted, through which a significant regression was found with $\mathrm{F}$ value, 56.5 , value of coefficient determination, 0.5461 , value of slope ( $\beta 1),-0.60023$, and $\mathrm{p}<0.0001$. Restelaff et al. (2016), in DMD development for Pinus taeda in Paraná, found a good fit of data with Reineke model. Thomas (2009) demonstrated that the Reineke model (1933) achieved a good fit in relation to the observed values (Figure 1), thus, adequate for the purpose.

For the adjustment of line $\mathrm{A}$, the value of the intercept was readjusted from 8.81664 to 9.05000 , thus being able to stay above all the observed values, thus representing the population in full density, including mortality of some trees. From the determination of line A, the DMD was developed, which in turn, aimed at thinning interventions to keep the basal area and the number of trees per hectare adequate, thus making space efficiently occupied.

Cárcamo et al. (2011), when using DMD as a management tool for forests of Drimys winteri in Chile, reported that between the density indexes of $40-55 \%$ maximum biomass production for energy use is obtained, and stands located in this area have a lower risk of falling due to wind. Figure 2 shows that the management range of the present study was between $50-55 \%$, coinciding with the work of Cárcamo et al. (2011).

Simulations presented in Tables 2 and 3 were built according to the data obtained from the sampled trees. The production of the forest was regulated in order to take advantage of the conditions provided by the sites, and maximising yield through activities suggested in the simulations.

In the first simulation, $\mathrm{G} \mathrm{ha}^{-1}$ of $21 \mathrm{~m}^{2} \mathrm{ha}^{-1}, \mathrm{Nr}$ $\mathrm{ha}^{-1}$ of 1550 and $\mathrm{dq}$ of $13 \mathrm{~cm}$ were determined, similar to the current stand situation. Based on these values, a moderate thinning was defined, through regulation of $8.8 \%$ of $\mathrm{G} \mathrm{ha}^{-1}$ and $19.2 \%$ of $\mathrm{Nr} \mathrm{ha}^{-1}$, equivalent to the reduction of $298 \mathrm{Nr}$ ha $^{-1}$.

The $\mathrm{dq}$ value of $17 \mathrm{~cm}$ was also defined for clearcut, which may reach $18 \mathrm{~cm}$ since the maximum diameter accepted for the purpose of this study was $18 \mathrm{~cm}$. Due to the current scenario described, and with an average dq increment of $2.41 \mathrm{~cm}$ year $^{-1}$, this method indicated thinning at 5.8 years and the clearcut at 7 years.

The simulation shown in Figure 3A begins from the current stand condition, starting at the point of thinning, near line C. From this point, the trees will find suitable conditions for their development until they reach a dq of $17 \mathrm{~cm}$ and $\mathrm{G} \mathrm{ha}^{-1}$ of 28.4 , close to line $\mathrm{B}$, when the clearcut should be performed.

It is evident that thinning practice was suggested due to the population being in competition. According to Cubas et al. (2016) excessive competition slows down the development of trees, which await the greater availability of light through opening of the canopy, and also of nutrients.

Intervention through thinning execution is extremely important for forest regulation, as the stand will be leveled, and the remaining trees will increase their dimensions quickly. Failure to carry out this silvicultural intervention will reduce the stand's development speed, causing its stagnation (Barbosa et al. 2015).

Thinning should be simulated from the moment when silvicultural interventions are needed. It is clear that the execution of two thinning would be necessary, as can be seen in Table 4 and Figure 3B. First thinning should be performed at 4 years of age, and another at 6 years of age, and the clearcut at 7.5 years.

When comparing simulation B with scenario A, it was possible to obtain a higher final value of $\mathrm{G} \mathrm{ha}^{-1}$ at clearcut, as well as a higher dq. For the second simulation, low thinning was suggested, that is, the suppression of trees with smaller diameter, which are normally dominant (Figure $3 \mathrm{~A})$. This is evident when observing that the value of $\mathrm{G} \mathrm{ha} \mathrm{h}^{-1}$ at the moment of thinning did not decrease, but remained constant.

It is also worth mentioning the importance of performing stand interventions as soon as trees start to compete. This can be realised with the aid of a DMD that describes the development of the stand leaves, the space included in the management range, and begins to have its growth 

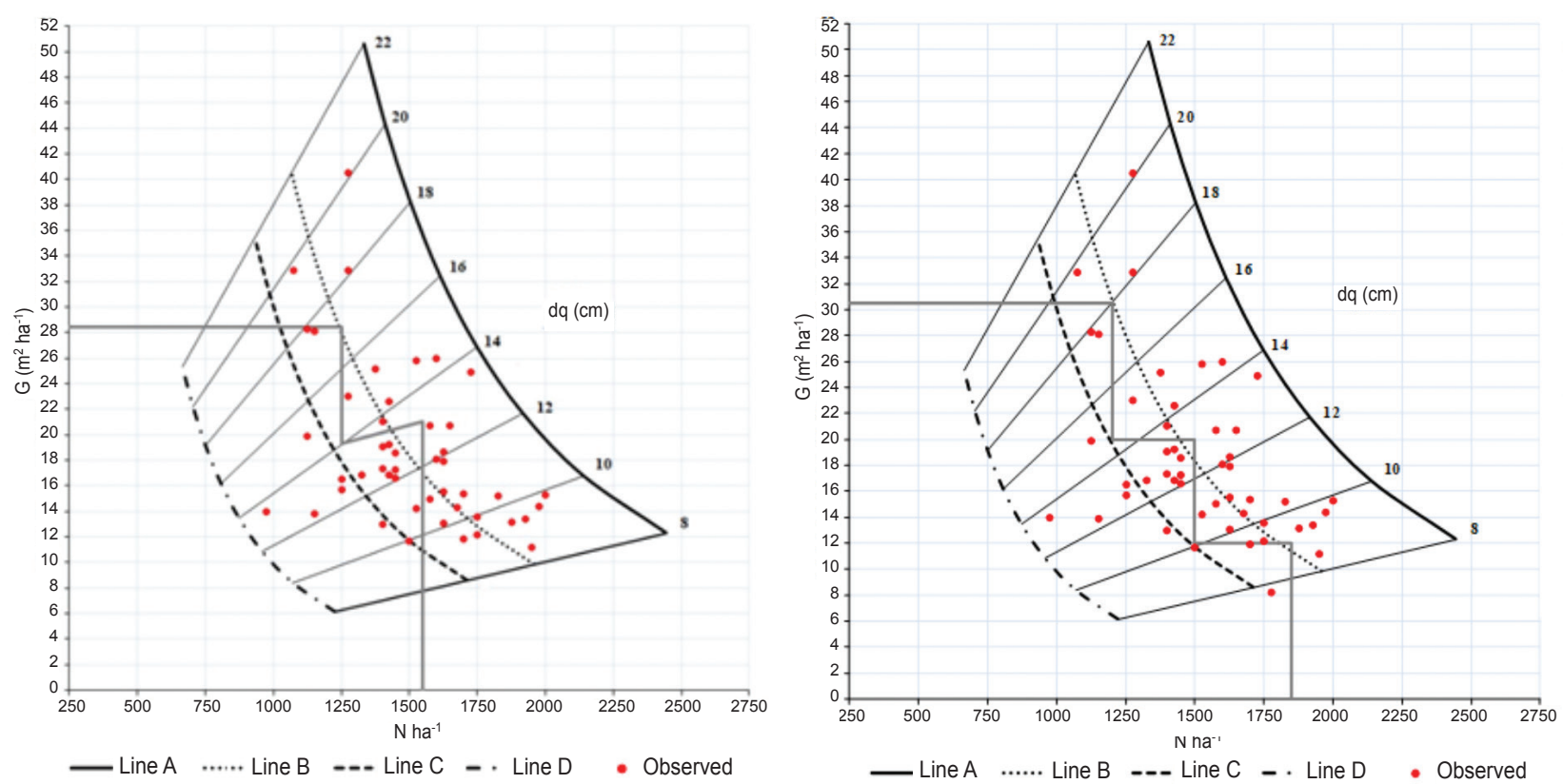

Figure 3 A and B simulation of the density management diagram (DMD) of the basal area $\left(\mathrm{G} \mathrm{ha}^{-1}\right) \mathrm{related}$ to the number of trees per hectare $\left(\mathrm{Nr} \mathrm{ha}^{-1}\right)$ and quadratic mean diameter (dq) for Eucalyptus dunnii stands located in Rio Negrinho, Santa Catarina, Brazil

compromised by competition between plants. Therefore, provision should be made at this time to avoid competition and the decreases in incremental rate, which causes economic losses (Scolforo et al. 1997)

Furthermore, the diagram shows the maximum tolerance capacity for trees to survive in the forest site. Thus, if forest intervention does not occur, the trees undergo self-thinning, since they are at or approaching carrying capacity and they cannot support the competition for water, light, space and nutrients, resulting in the mortality of the dominated trees (Walker 2020, Schneider 2008).

Zhang et al. (2020) highlights that the selfthinning rule in even-aged stands has been a basic topic of research and discussion for more than 80 years. In view of that, the DMD studies should be used to enrich forest management practices. The study of artificial selection on tolerance to competition can potentially increase harvest yield without sacrificing growth rate (Walker et al. 2020).

It is recommended that other studies with different spacing be performed so that the construction of DMD has better results, in order to further assist the establishment of forest management and planning strategies, for yield prognosis. In addition, research with other spacing may assist regarding the use of larger spacing when planting, or thinning.
Furthermore, economic analyses of thinning must also be carried out.

\section{CONCLUSION}

According to the results, the DMD constructed with quadratic mean diameter, basal area and number of trees per hectare proved to be efficient for estimates. With DMD it was possible to establish forest management strategies through two simulations, one starting from the moment when interference should have been taken, and the other describing the current situation and proposing practices.

\section{REFERENCE}

Alvares CA, Stape Jl, Sentelhas PC et al. 2014. Köppen's climate classification map for Brazil. Meteorologische Zeitschrift 22: 711-728. https://doi. org/10.1127/0941-2948/2013/0507.

Barbosa RHS, Fiedler NC, Alves EG et Al. 2015. Análise técnica e econômica do desbaste em um povoamento de eucalipto na região sul do Espírito Santo. Nativa 3: 125-130. https://doi.org/10.31413/nativa. v3i2.2009.

Bognola IA, 2007. Unidades de manejo para Pinus taeda L. no planalto norte catarinense, com base em características do meio físico. PhD thesis, Universidade Federal do Paraná, Parana.

Cárcamo CN, Herrera MA, Aranda FD et al. 2011. Diagrama de manejo de densidad y su aplicación a raleo en bosques de segundo crecimiento de Drimys winterien 
el sur de Chile. Bosque 32: 175-186. http:/ /dx.doi. org/10.4067/S0717-92002011000200008.

Costa EA, Finger CAG, Fleig FD et al. 2016. Dendrograma de manejo da densidade para uma floresta inequiânea de araucária. Floresta 46: 173-184. http://dx.doi.org/10.5380/rf.v46i2.43449.

Cubas R, Farinha LW \& Figueiredo Filho A. 2015. Incremento, ingresso, mortalidade em um remanescente de Floresta Ombrófila Mista em Três Barras-SC. Ciência Florestal 26: 889-900. https:/ / doi. org/10.5902/1980509824216.

INPE (Instituto Nacional de Pesquisas Espaciais). 2009 http://bancodedados.cptec.inpe.br/climatologia/ Controller.

Kobiyama M, Checchia T, Corseuil CW et al. 2007. Forest hydrology project (UFSC MOBASA) for water resources managemente in Rio Negrinho City, Santa Catarina, Brazil. IAHS-AISH Publication 315: 250-257.

Lima R, Inoue MT, Figueiredo Filho A et al. 2013. Efeito do espaçamento no desenvolvimento volumétrico de Pinus taeda L. Floresta e Ambiente 20: 223-230. https://doi.org/10.4322/floram.2013.001.

Long JN \& Smith FW. 1985. Relation between size and density in developing stands: a description and possible mechanisms. Forest Ecology and Management 7: 191-206. https://doi.org/10.1016/0378$1127(84) 90067-7$.

Marangon GP. 2015. Otimização bioeconômica do regime de manejo para Eucalyptus grandis W. Hill no estado do Rio Grande do Sul. PhD thesis, Universidade Federal de Santa Maria, Santa Maria.

Marangon GP, Schneider PR, Zimmermann APL et al. 2017. Density management diagrams for stands of Eucalyptus grandis W. Hill RS, Brazil. Revista Árvore 41: e410108. http://dx.doi.org/10.1590/180690882017000100008 .

Fatma N, Wan Juliana W, Shaharuddin M et al. 2020. Stand structure of shorea and spatial distribution of Shorea acuminata in a rehabilitated area of Kenaboi forest reserve. Journal of Tropical Forest Science 32: 257-267. https://doi.org/10.2307/26921873.

REID R. 2004. Silvicultural management of Australian blackwood (Acacia melanoxylon) in plantations and multi-purpose forests. In: Pp 70-74 in Gove JH (ed) Structural Stocking Guides: A New Look At An
Old Friend. Canadian Science Publishing, Ottawa. https://doi.org/10.1139/x03-272.

Reineke LH. 1993. Perfecting a stand-density index for even-aged forests. Journal of Agricultural Research 46: 627-638.

Retslaff FAZ, Figueiredo Filho A, Machado AS et al. 2016. Diagrama de manejo da densidade para Pinus taeda no estado do Paraná. Floresta 46: 185-195. http:// dx.doi.org/10.5380/rf.v46i2.38301.

SCHEeren LW, SCHNeIder PR \& Finger CAG. 2004. Crescimento e produção de povoamentos monoclonais de Eucalyptus saligna Smith manejados com desbaste, na região sudeste do Estado do Rio Grande do Sul. Ciência Florestal 14: 111-122. http://dx.doi. org/10.5902/198050981811.

SCHNEIDER PSP. 2008. Autodesbaste e diagrama de manejo da densidade em povoamentos de Pinus taeda L. MSc thesis, Universidade Federal de Santa Maria, Santa Maria.

Schneider PSP, Fleig FD, Schneider PR et AL. 2009. Diagrama de manejo da densidade para povoamento de Pinus taeda L. conduzido sem desbaste. Ciência Florestal 19: 433-447. http://dx.doi.org/10.5902/19805098898.

SCHNeIDER PR. 2004. Manejo Florestal: Planejamento Da Produção Florestal. Universidade Federal de Santa Maria, Santa Maria.

Scolforo JRS, Maestri R \& Machado AS. 1997. Um modelo de crescimento e produção como suporte para manejo florestal. Pp 1-31 in Paulenir C (ed) Curso De Manejo Florestal Sustentável, Anais Embrapa, Colombo.

Selle GL, Vuaden E, Braz EM et al. 2010. Uso do dendrograma de manejo de densidade: uma aplicação prática com Hovenia dulcis Thunberg. Scientia Forestalis 38: 247- 254.

Thomas C. 2009. Dendrograma de manejo da densidade para povoamentos de Pinus elliottii Engelm na Região Central do Rio Grande do Sul. MSc thesis, Universidade Federal de Santa Maria, Santa Maria.

Walker TD, Bullock BP, SMith BC et AL. 2020. Modeling selfthinning patterns in loblolly pine with provenance and family effects. Forest Science 66: 712-725. https:// doi.org/10.1093/forsci/fxaa030.

Zhang X, Cao QV, Wang H et al. 2020. Projecting stand survival and basal area based on a self-thinning model for Chinese Fir Plantations. Forest Science 66: 361-370. https://doi.org/10.1093/forsci/fxz086. 